TUBERCULAR CAPITAL 
STANFORD STUDIES IN JEWISH HISTORY AND CULTURE Edited by David Biale and Sarah Abrevaya Stein 


\title{
TUBERCULAR CAPITAL
}

Illness and the Conditions of

\author{
Modern Jewish Writing
}

\author{
SUNNY S. YUDKOFF
}

Stanford University Press

Stanford, California 
Stanford University Press

Stanford, California

(C) 2019 by the Board of Trustees of the Leland Stanford Junior University.

All rights reserved.

No part of this book may be reproduced or transmitted in any form or by any means, electronic or mechanical, including photocopying and recording, or in any information storage or retrieval system without the prior written permission of Stanford University Press.

Printed in the United States of America on acid-free, archival-quality paper

Library of Congress Cataloging-in-Publication Data

Names: Yudkoff, Sunny S., author.

Title: Tubercular capital : illness and the conditions of modern Jewish writing / Sunny S. Yudkoff.

Description: Stanford, California : Stanford University Press, 2018. | Series: Stanford studies in Jewish history and culture | Includes bibliographical references and index.

Identifiers: LCCN 2018019693 (print) | LCCN 2018038493 (ebook) | ISBN 9781503607330 | ISBN 9781503605152 (cloth: alk. paper)

Subjects: LCSH: Tuberculosis in literature. | Hebrew literature, Modern—2oth centuryHistory and criticism. | Yiddish literature—2oth century-History and criticism. | Jewish literature— 20 th century-History and criticism. | Jewish authors-DiseasesHistory. | Tuberculosis patients' writings-History and criticism. | Tuberculosis and literature.

Classification: LCC PJ50I2.T83 (ebook) | LCC PJ50I2.T83 Y83 2018 (print) | DDC $839 / .109356 \mathrm{I}-\mathrm{dc} 23$

LC record available at https://lccn.loc.gov/2018019693

Cover design: Rob Ehle

Cover illustration: Drawing of the Hebrew poet Rahel Bluvshtein by Aba Fenichel. 